\title{
Is utilization of health services for HIV patients equal by socioeconomic status? Evidence from the Basque country
}

\author{
Manuel García-Goñi ${ }^{*}$, Roberto Nuño-Solinís ${ }^{2}$, Juan F. Orueta ${ }^{3}$ and Francesco Paolucci ${ }^{4,5}$
}

\begin{abstract}
Introduction: Access to ART and health services is guaranteed under universal coverage to improve life expectancy and quality of life for HIV patients. However, it remains unknown whether patients of different socioeconomic background equally use different types of health services.

Methods: We use one-year (2010-2011) data on individual healthcare utilization and expenditures for the total population ( $\mathrm{N}=2262698)$ of the Basque Country. We observe the prevalence of HIV and use OLS regressions to estimate the impact on health utilization of demographic, socioeconomic characteristics, and health status in such patients.

Results: HIV prevalence per 1000 individuals is greater the lower the socioeconomic status (0.784 for highest; 2.135 for lowest), for males (1.616) versus females (0.729), and for middle-age groups (26-45 and 46-65). Health expenditures are $11826 €$ greater for HIV patients than for others, but with differences by socioeconomic group derived from a different mix of services utilization (total cost of 13058€ for poorest, 14960€ for richest). Controlling for health status and demographic variables, poor HIV patients consume more on pharmaceuticals; rich in specialists and hospital care. Therefore, there is inequity in health services utilization by socioeconomic groups.

Conclusions: Equity in health provision for HIV patients represents a challenge even if access to treatment is guaranteed. Lack of information in poorer individuals might lead to under-provision while richer individuals might demand over-provision. We recommend establishing accurate clinical guidelines with the appropriate mix of health provision by validated need for all socioeconomic groups; promoting educational programs so that patients demand the appropriate mix of services, and stimulating integrated care for HIV patients with multiple chronic conditions.
\end{abstract}

Keywords: Inequities, Socioeconomic status, ART, HIV, Universal coverage

\section{Introduction}

The Human Immunodeficiency Virus (HIV) is a global public health issue with more than 36 million affected. The highest prevalence is found in Sub-Saharan Africa where nearly $5 \%$ of adults live with HIV, being $69 \%$ of all people living with HIV in the world [1]. Although HIV mortality was huge in the 1980s, the development in the 1990s of highly active antiretroviral therapy (ART) was determinant to reduce rates of death and

\footnotetext{
* Correspondence: mggoni@ucm.es

'Departamento de Economía Aplicada II, Universidad Complutense de Madrid, Campus de Somosaguas, 28223 Pozuelo de Alarcón, Madrid, Spain
} Full list of author information is available at the end of the article mother-to-child transmission. However, only in developed countries, with general access to ART, HIV behaves as a chronic condition. By 2012, more than half of the HIV world population is in developing countries with inequalities in the access to ART and with a huge rate of mortality [2].

Hence, there are two completely different realities in health policy and planning when looking at HIV. First, in developed countries with mostly universal access to ART, HIV is a chronic condition. There, the challenge in health systems is to become high-performing chronic care systems [3] and efficient given the increasing evolution of health expenditures [4]. That is feasible by 
looking at the way in which health services are provided [5] to chronic patients and to whether patients are suffering more than one chronic condition at the same time [6] in order to adapt their demand to their need. Here, it remains unknown whether there is equity in the use of health services by patients of different socioeconomic background even when access is guaranteed by the health system. Second, in low and middle-income countries where the challenge is to increase the access to ART [7]. Worldwide, inequity in access is a crucial challenge dealing with HIV. However, most studies look at inequity from the second perspective, focusing on increasing international rates of access to ART where it is needed [8], its role on prevention [9], on mortality [10], its impact in different groups of individuals as sex workers [11] or injecting drug users [12], or early diagnosis in infants [13]. We contribute to the literature by developing a different analysis looking at the first mentioned reality: HIV health policy and planning in developed countries where access to ART is guaranteed.

We look at the Basque Country, a region in Spain, where access to public healthcare services is universal and free at the point of use, where ART is free and patients only pay a copayment rate in other pharmacological treatments [14]. We utilize individual data from the entire Basque population (2.26 million inhabitants) on diagnoses, socioeconomic information and standardized health expenditures. We test whether patients of different socioeconomic background equally use different types of health services.

\section{Data and methods}

We utilize the database prepared by the population stratification program (PREST) of the Basque Country including the practical totality of its population: every individual covered on 31 August 2011 by the public health insurance in the Basque Country and who was covered for at least 6 months in the previous year, regardless of whether they made any contact with or use of the Basque Health Service. The analysis refers to one year, from September $1^{\text {st }}, 2010$ to August $31^{\text {st }}, 2011$. There are 2,262,698 individuals, being $50.90 \%$ female. As for the age distribution, $15 \%$ are children (younger than 18 ) and $20 \%$ are over 65 , being the average individual 43.69 years old. It is therefore important to remark that it is not a random sample but the real population in terms of health policy and planning.

Our dataset combines three types of information. First, diagnoses information is based on hospital discharges, emergency department, primary care medical records, and prescriptions. They all are coded according to the ICD-9CM [15] (diagnoses) and ATC [16] (pharmaceuticals). Second, out of utilization we obtain individual standardized health expenditures. Third, we utilize socioeconomic information. For the sake of our analysis, we only look at the HIV diagnosis in order to differentiate among HIV patients and non-HIV reported individuals. With respect to health expenditures, the cost of the public health services provision is based on use. However, there are no market prices within the Basque Health Service and costs are estimated through standardization of total health expenditures per type of service. We take into account the number of visits to primary care, specialist care, Accident \& Emergency, rehabilitation sessions, outpatient care, laboratory tests, radiological examinations, and various outpatient procedures such as dialysis, radiotherapy and chemotherapy. Cost of hospitalization and outpatient surgery is assigned through the cost-weights of the corresponding diagnosis-related groups (DRGs). Finally, the cost of ART, provided in public hospitals in the Basque Country, has been calculated as the average cost of all ART provided in 2012. Total number of patients with ART was 5002 and total expenditure in ART treatment was of $38501376 €$, for an average cost per treatment of $7697 €$. Finally, the cost of pharmaceutical prescriptions (excluding ART) recorded in electronic health records is based on market prices. Information on socioeconomic status is derived out of the deprivation index (DI), an ordinal variable elaborated for Spain in 2008 [17] categorizing into five socioeconomic groups (SEG) by quintiles. The DI allows for the estimation of socioeconomic and environmental inequities among inhabitants by censal code. It takes into account five dimensions including the percentages of residents who are manual workers, unemployed, temporary employees, or have an inadequate level of educational attainment, overall and also specifically among young people.

We use OLS regressions to identify whether there are inequities in the use of of health services provision of any type for HIV patients in a population in which access to ART and other treatments is free and granted. Following the risk adjustment literature, our dependent variable is health expenditures for HIV patients on age groups, which, as mentioned above, is directly related to the utilization of health services (standardized health expenditures by use). With respect to our independent variables, because we do not observe all variables that might affect health expenditures we use fixed effect by socioeconomic groups (SEG). We do the same for the different types of health expenditures (provision) and for total health expenditures. In that further estimation approach, we take into account the individual age and the number of chronic conditions suffered as the risk adjustment literature states that greater need of health provision derives in greater expected health expenditure [18]. The aim is to control for healthcare needs, taking the individual number of comorbidities as a proxy. In order to construct those variables, we utilize a 
list of 52 health conditions defined by the research team based on the related literature [19-21]. We capture the role of multimorbidities by defining three categories: 1 to 3 comorbidities, 4 to 6 , and 7 or more. The specification for our estimation model is given by:

Health Expenditures ${ }_{i}=\sum_{j} \alpha_{j} a g e_{i j}+\sum_{k} \beta_{k} S E G_{k i}+\sum_{l} \delta_{l} N M o r b_{l i}+\varepsilon_{i}$

\section{Results}

Table 1 presents a description of the Basque Country population and its prevalence of HIV as a function of the demographic, socioeconomic characteristics, and by gender and age groups subject to the PREST dataset. Prevalence for the total population is of 1.164 per 1000 individuals. HIV prevalence is more than double for males than for females (1.616 vs 0.729 ) although for young individuals from 16 to 25 , females present a greater prevalence $(0.245$ vs 0.192$)$. More than half of all HIV-reported patients belong to the group of 46 to 65 years old (1361 out of 2635), being also important the group of those from 26 to 45 (1135 cases). The remaining age groups also have HIV patients although prevalence is very small. Interestingly, we observe the process of ageing in the HIV population with 8 cases of HIV patients older than 80 . Finally, HIV prevalence decreases with socioeconomic status (being from richest to poorest SEG $0.784,0.819,1.095,1.114$, and 2.135 respectively), with significant differences between the first two SEG, the third and fourth, and the poorest SEG that presents a prevalence three times that of the richest SEG and almost double that of the total population. Socioeconomic status makes a difference in prevalence for age groups older than 26, being highest for the poorest SEG between 46 and 65 years old (prevalence ratio of 4.208).

Provided their health service utilization, the Basque population presents an average total health expenditures of $1132 €$, being of $1118 €$ for non-HIV (reported) individuals, and of $13260 €$ for HIV patients. Table 2 shows expenditures by type of health service and for non-HIV and HIV patients. Hospitalization is the most expensive type of health service (372€), being the second Primary Care $(261 €)$ and the third specialist care $(255 €)$. Differently, ART $(7687 €)$ is the most expensive type of provision for HIV patients, being second hospitalization (3372€), and third specialist care (1334€). Although for every type of provision HIV patients are more expensive than non-HIV in absolute terms, it is worth to look at relative expenditures. ART represents $58.05 \%$ of total health expenditures for HIV patients. However, if we take for granted ART and do not take it into account, relative weight of expenditures on hospitalization are much more important for HIV patients $(60.62 \%$ vs $33.32 \%)$ and some greater for specialist care (23.99\% vs $22.87 \%)$ while relative expenditures on
A\&E ( $4.83 \%$ vs $3.25 \%)$, primary care $(23.33 \%$ vs $6.80 \%)$ and pharmaceutical prescriptions (15.65 \% vs $5.34 \%)$ are greater for non-HIV patients.

Table 3 presents the average cost for HIV patients by provider and SEG. The cost on ART, by construction, has been considered to be identical for all individuals. Primary care and pharmaceutical prescriptions are more used by poorer individuals while hospitalization and specialist care are more used by richest individuals. Precisely, those are the most expensive types of health provision without taking ART into account. Consequently, the Basque Country allocates a greater amount of public health resources in HIV patients in the richest SEG (14960€) while it allocates lower resources in HIV patients in the poorest SEG $(13058 €)$, and lowest for the third SEG (12585€). Figure 1 crosses the prevalence ratio and average total health expenditures for the five socioeconomic groups. While prevalence is negatively related to socioeconomic status (lower prevalence for richer SEG), total health expenditures for HIV patients is highest for the richest SEG and the trend of both series seems to be opposite. Figure 2 shows the proportion of HIV patients with different numbers of comorbidities by SEG. Even if there are some differences, the distribution of chronic conditions is similar in each SEG and for the total HIV population having about $76 \%$ of them at least another chronic condition.

Our regression analysis is presented in Table 4. For every type of health provision we run different age groups as explanatory variables. We then add to the estimation the independent variables corresponding to the socioeconomic status and morbidity burden through the number of chronic conditions. Our main result show how socioeconomic status is significant for any type of health provision even controlling for healthcare need through the number of chronic diseases suffered by patients. Thus, patients of different SEG seem to utilize differently health providers: HIV patients in the richest SEG significantly use more specialist and hospital care while those in poorest SEG ( $4^{\text {th }}$ and $5^{\text {th }}$ ) utilize slightly more only on primary care and pharmaceutical prescriptions. Differences in the significant coefficients between richest and lowest SEG for hospital and specialist care expenditures are of $2072.9 €(12967.66 €-10894.76 €)$ and $388.11 €(2918.92 €-2530.81 €)$ while differences between lowest and richest SEG in primary care and pharmaceutical expenditures are of $21.64 €(990.29 €-968.65 €)$ and $31.06 €(962.66 €-931.60 €)$. Consequently, our results support the existence of inequities in the provision of health services for HIV patients by SEG once controlling for their health status. This finding is aligned with others in the literature, with specialist treatment being pro-rich within the British NHS when looking at several chronic conditions (others than HIV) [22]. With respect to our other control variables, age is only important when it is 
Table 1 HIV prevalence ratio by socio-demographic groups in the Basque Country

\begin{tabular}{|c|c|c|c|c|c|c|}
\hline & \multicolumn{2}{|c|}{ Target population } & \multicolumn{2}{|l|}{ HIV } & \multirow{2}{*}{$\begin{array}{l}\text { Prevalence } \\
\text { ratio per } \\
1000 \\
\text { population }\end{array}$} & \multirow{2}{*}{$\begin{array}{l}\text { Prevalence } \\
\text { with } \\
\text { respect to } \\
\text { the } \\
\text { population } \\
\text { average }\end{array}$} \\
\hline & $\bar{N}$ & $\%$ & $\bar{N}$ & $\%$ & & \\
\hline All & $2,262,698$ & 100 & 2635 & 100 & 1.165 & 1.00 \\
\hline \multicolumn{7}{|l|}{ Sex groups } \\
\hline Males & $1,111,050$ & 49.10 & 1796 & 68.16 & 1.616 & 1.39 \\
\hline Females & $1,151,648$ & 50.90 & 839 & 31.84 & 0.729 & 0.63 \\
\hline \multicolumn{7}{|l|}{ Age groups } \\
\hline Age 0 to 15 & 305,573 & & 16 & & 0.052 & 0.04 \\
\hline Males & 157,884 & 51.67 & 10 & 62.50 & 0.063 & 0.05 \\
\hline Females & 147,689 & 48.33 & 6 & 37.50 & 0.041 & 0.03 \\
\hline Age 16 to 25 & 192,636 & & 42 & & 0.218 & 0.19 \\
\hline Males & 98,802 & 51.29 & 19 & 45.24 & 0.192 & 0.17 \\
\hline Females & 93,834 & 48.71 & 23 & 54.76 & 0.245 & 0.21 \\
\hline Age 26 to 45 & 715,995 & & 1135 & & 1.585 & 1.36 \\
\hline Males & 366,970 & 51.25 & 702 & 61.85 & 1.913 & 1.64 \\
\hline Females & 349,025 & 48.75 & 433 & 38.15 & 1.241 & 1.07 \\
\hline Age 46 to 65 & 621,406 & & 1361 & & 2.190 & 1.88 \\
\hline Males & 307,222 & 49.44 & 1010 & 74.21 & 3.288 & 2.82 \\
\hline Females & 314,184 & 50.56 & 351 & 25.79 & 1.117 & 0.96 \\
\hline Age 66 to 80 & 298,687 & & 73 & & 0.244 & 0.21 \\
\hline Males & 135,878 & 45.49 & 50 & 68.49 & 0.368 & 0.32 \\
\hline Females & 162,809 & 54.51 & 23 & 31.51 & 0.141 & 0.12 \\
\hline Age over 80 & 128,401 & & 8 & & 0.062 & 0.05 \\
\hline Males & 44,294 & 34.50 & 5 & 62.50 & 0.113 & 0.10 \\
\hline Females & 84,107 & 65.50 & 3 & 37.50 & 0.036 & 0.03 \\
\hline \multicolumn{7}{|c|}{ Socioeconomic groups } \\
\hline First SEG & 479,316 & & 376 & & 0.784 & 0.67 \\
\hline Males & 228,747 & 47.72 & 252 & 67.02 & 1.102 & 0.95 \\
\hline Females & 250,569 & 52.28 & 124 & 32.98 & 0.495 & 0.42 \\
\hline Second SEG & 487,140 & & 399 & & 0.819 & 0.70 \\
\hline Males & 238,951 & 49.05 & 277 & 69.42 & 1.159 & 1.00 \\
\hline Females & 248,189 & 50.95 & 122 & 30.58 & 0.492 & 0.42 \\
\hline Third SEG & 457,665 & & 501 & & 1.095 & 0.94 \\
\hline Males & 226,345 & 49.46 & 353 & 70.46 & 1.560 & 1.34 \\
\hline Females & 231,320 & 50.54 & 148 & 29.54 & 0.640 & 0.55 \\
\hline Fourth SEG & 422,729 & & 471 & & 1.114 & 0.96 \\
\hline Males & 209,966 & 49.67 & 309 & 65.61 & 1.472 & 1.26 \\
\hline Females & 212,763 & 50.33 & 162 & 34.39 & 0.761 & 0.65 \\
\hline Fifth SEG & 415,848 & & 888 & & 2.135 & 1.83 \\
\hline Males & 207,041 & 49.79 & 605 & 68.13 & 2.922 & 2.51 \\
\hline Females & 208,807 & 50.21 & 283 & 31.87 & 1.355 & 1.16 \\
\hline All & $2 E+06$ & 100 & 2635 & 100 & 1.165 & 1.00 \\
\hline
\end{tabular}

Socioeconomic groups 
Table 1 HIV prevalence ratio by socio-demographic groups in the Basque Country (Continued)

\begin{tabular}{|c|c|c|c|c|c|c|}
\hline First SEG & 479,316 & & 376 & & 0.784 & 0.67 \\
\hline Age 0 to 15 & 67,569 & 14.10 & 3 & 0.80 & 0.044 & 0.04 \\
\hline Age 16 to 25 & 45,043 & 9.40 & 1 & 0.27 & 0.022 & 0.02 \\
\hline Age 26 to 45 & 137,891 & 28.77 & 149 & 39.63 & 1.081 & 0.93 \\
\hline Age 46 to 65 & 140,490 & 29.31 & 206 & 54.79 & 1.466 & 1.26 \\
\hline Age 66 to 80 & 60,085 & 12.54 & 16 & 4.26 & 0.266 & 0.23 \\
\hline Age over 80 & 28,238 & 5.89 & 1 & 0.27 & 0.035 & 0.03 \\
\hline Second SEG & 487,140 & & 399 & & 0.819 & 0.70 \\
\hline Age 0 to 15 & 69,980 & 14.37 & 4 & 1.00 & 0.057 & 0.05 \\
\hline Age 16 to 25 & 42,220 & 8.67 & 10 & 2.51 & 0.237 & 0.20 \\
\hline Age 26 to 45 & 152,153 & 31.23 & 160 & 40.10 & 1.052 & 0.90 \\
\hline Age 46 to 65 & 135,980 & 27.91 & 205 & 51.38 & 1.508 & 1.29 \\
\hline Age 66 to 80 & 60,097 & 12.34 & 18 & 4.51 & 0.300 & 0.26 \\
\hline Age over 80 & 26,710 & 5.48 & 2 & 0.50 & 0.075 & 0.06 \\
\hline Third SEG & 457,665 & & 501 & & 1.095 & 0.94 \\
\hline Age 0 to 15 & 65,088 & 14.22 & 3 & 0.60 & 0.046 & 0.04 \\
\hline Age 16 to 25 & 37,706 & 8.24 & 10 & 2.00 & 0.265 & 0.23 \\
\hline Age 26 to 45 & 146,271 & 31.96 & 210 & 41.92 & 1.436 & 1.23 \\
\hline Age 46 to 65 & 125,084 & 27.33 & 269 & 53.69 & 2.151 & 1.85 \\
\hline Age 66 to 80 & 58,785 & 12.84 & 9 & 1.80 & 0.153 & 0.13 \\
\hline Age over 80 & 24,731 & 5.40 & 0 & 0.00 & 0.000 & 0.00 \\
\hline Fourth SEG & 422,729 & & 471 & & 1.114 & 0.96 \\
\hline Age 0 to 15 & 47,674 & 11.28 & 3 & 0.64 & 0.063 & 0.05 \\
\hline Age 16 to 25 & 34,220 & 8.10 & 11 & 2.34 & 0.321 & 0.28 \\
\hline Age 26 to 45 & 138,400 & 32.74 & 205 & 43.52 & 1.481 & 1.27 \\
\hline Age 46 to 65 & 115,524 & 27.33 & 242 & 51.38 & 2.095 & 1.80 \\
\hline Age 66 to 80 & 61,759 & 14.61 & 7 & 1.49 & 0.113 & 0.10 \\
\hline Age over 80 & 25,152 & 5.95 & 3 & 0.64 & 0.119 & 0.10 \\
\hline Fifth SEG & 415,848 & & 888 & & 2.135 & 1.83 \\
\hline Age 0 to 15 & 55,262 & 13.29 & 3 & 0.34 & 0.054 & 0.05 \\
\hline Age 16 to 25 & 33,447 & 8.04 & 10 & 1.13 & 0.299 & 0.26 \\
\hline Age 26 to 45 & 141,280 & 33.97 & 411 & 46.28 & 2.909 & 2.50 \\
\hline Age 46 to 65 & 104,328 & 25.09 & 439 & 49.44 & 4.208 & 3.61 \\
\hline Age 66 to 80 & 57,961 & 13.94 & 23 & 2.59 & 0.397 & 0.34 \\
\hline Age over 80 & 23,570 & 5.67 & 2 & 0.23 & 0.085 & 0.07 \\
\hline
\end{tabular}

the only risk adjuster used, and the number of chronic conditions suffered by the patient explains health utilization of any type and total health expenditures, as usual in the risk adjustment literature [18], being most of the significant differences produced by the different use of hospital and specialist care. Hence, it is important to account for multimorbidity in order to understand the different level of utilization of health services by socioeconomic status, especially because patients with multiple conditions are the most expensive ones and therefore, those for whom health policy makers should pay more attention to their mix of health services provision.

\section{Discussion}

We find evidence of inequity in the use of health services of different type in HIV patients by socioeconomic status. While rich HIV patients use in average more of hospital and specialist care, poor HIV patients use in average more of primary care and spend more in pharmaceutical products, other than the ART treatment, common to all patients. With respect to demographic 
Table 2 Descriptive cost per type of health service for HIV and non-HIV individuals

\begin{tabular}{|c|c|c|c|c|c|c|c|}
\hline \multirow[b]{2}{*}{$\begin{array}{l}\text { Cost in different types of } \\
\text { health services }\end{array}$} & \multicolumn{2}{|l|}{ All } & \multicolumn{2}{|c|}{ Not-HIV patients } & \multicolumn{3}{|l|}{ HIV patients } \\
\hline & $\begin{array}{l}\text { Mean } \\
\text { (std.dev.) }\end{array}$ & $\%$ & $\begin{array}{l}\text { Mean } \\
\text { (std.dev.) }\end{array}$ & $\%$ & $\begin{array}{l}\text { Mean } \\
\text { (std.dev.) }\end{array}$ & $\begin{array}{l}\% \text { of total expenditure } \\
\text { with ART }\end{array}$ & $\begin{array}{l}\% \text { of total expenditure } \\
\text { without ART }\end{array}$ \\
\hline Primary Care $(€)$ & $\begin{array}{l}261.14 \\
(327.62)\end{array}$ & $23.05 \%$ & $\begin{array}{l}261.00 \\
(327.50)\end{array}$ & $23.33 \%$ & $\begin{array}{l}378.19 \\
(394.87)\end{array}$ & $2.85 \%$ & $6.80 \%$ \\
\hline Specialist Care $(€)$ & $\begin{array}{l}257.08 \\
(999.97)\end{array}$ & $22.69 \%$ & $\begin{array}{l}255.82 \\
(995.98)\end{array}$ & $22.87 \%$ & $\begin{array}{l}1334.73 \\
(2583.12)\end{array}$ & $10.07 \%$ & $23.99 \%$ \\
\hline Accidents and Emergency $(€)$ & $\begin{array}{l}54.20 \\
(142.78)\end{array}$ & $4.78 \%$ & $\begin{array}{l}54.06 \\
(142.01)\end{array}$ & $4.83 \%$ & $\begin{array}{l}180.64 \\
(438.16)\end{array}$ & $1.36 \%$ & $3.25 \%$ \\
\hline Hospitalizations ( $£$ ) & $\begin{array}{l}376.29 \\
(2294.01)\end{array}$ & $33.21 \%$ & $\begin{array}{l}372.79 \\
(2269.33)\end{array}$ & $33.32 \%$ & $\begin{array}{l}3372.62 \\
(9638.71)\end{array}$ & $25.43 \%$ & $60.62 \%$ \\
\hline $\begin{array}{l}\text { Pharmaceutical Prescriptions } \\
(€)\end{array}$ & $\begin{array}{l}175.21 \\
(513.43)\end{array}$ & $15.47 \%$ & $\begin{array}{l}175.07 \\
(513.11)\end{array}$ & $15.65 \%$ & $\begin{array}{l}297.22 \\
(726.50)\end{array}$ & $2.24 \%$ & $5.34 \%$ \\
\hline ART Treatment $\{€)$ & $8.96(262.51)$ & $0.79 \%$ & 0.00 & $0.00 \%$ & $7697.00(0.00)$ & $58.05 \%$ & - \\
\hline Total Cost $(€)$ & $\begin{array}{l}1132.90 \\
(3152.11)\end{array}$ & $100.00 \%$ & $\begin{array}{l}1118.76 \\
(3102.18)\end{array}$ & $100.00 \%$ & $\begin{array}{l}13260.40 \\
(11425.49)\end{array}$ & $100.00 \%$ & $100.00 \%$ \\
\hline $\mathrm{N}$ & $2,262,698$ & & $2,260,063$ & & 2635 & & \\
\hline
\end{tabular}

variables, HIV prevalence is greater for males and at poorer socioeconomic groups. At the same time, we find evidence of the ageing and "chronification" process of the HIV population because there are patients older than 80 and most of them (76\%) suffer from other conditions.

Inequity in the access to health services and ART has been extensively studied in low-income countries and the evidence of its existence is a public concern. The access to treatment is determinant to increase quality of life and expectancy of life of HIV patients, as well as for prevention and to allow patients to be and feel part of the society and contribute to economic activity [23]. Most high-income countries, differently, present universal health systems where access to ART for HIV patients and other health services provision is guaranteed and many times, free at the point of use. That is the case in the Basque Country, a region in Spain responsible for health policy, planning, and provision for its entire population. However, we contribute to the literature finding that even when access is guaranteed, there is still inequity in the use of health services.
Hence, the fact that universal health systems ensure equal right to use health services for everyone, and that all HIV patients obtain ART, do not mean that they have achieved equity in the use of different types of health services. Our analysis does not determine which is the optimal mix of health services provision for HIV patients and it is not clear, with our data, whether there is over-provision (under-provision) for the richest (poorest) of specialist or hospital care. In fact, it cannot be directly inferred that there exists discrimination. That question is out of the scope in this paper. We add our result to the literature on the inconclusive effect of health literacy in HIV patients [24]. Our interpretation is that we might have identified the existence of some barriers that prevent poorest patients to demand equally those services even when there is universal care with free provision at the point of use. Although more research is needed to determine the existence of those barriers, we point to lack of information or a different educational level associated to each socioeconomic group that might affect the way in which they understand how to demand specialist or hospital care, or the role of the GP as a gatekeeper. A better

Table 3 Average cost per type of health expenditure for HIV patients by socioeconomic group (SEG)

\begin{tabular}{llllll}
\hline & First SEG N=376 & Second SEG N=399 & Third SEG N=501 & Fourth SEG N=471 & Fifth SEG N=888 \\
Cost in different types of health services & Mean (std. Dev.) & Mean (std. Dev.) & Mean (std. Dev.) & Mean (std. Dev.) & Mean (std. Dev.) \\
\hline Primary Care $(€)$ & $357.01(352.78)$ & $373.69(357.68)$ & $370.82(371.14)$ & $388.54(407.68)$ & $387.84(432.31)$ \\
Specialist Care $(€)$ & $1656.69(3134.08)$ & $1266.92(1458.59)$ & $1123.16(1620.72)$ & $1340.54(1795.35)$ & $1345.16(3383.37)$ \\
Accidents and Emergency $(€)$ & $178.23(339.81)$ & $179.46(373.76)$ & $159.11(294.87)$ & $185.16(364.54)$ & $191.94(582.04)$ \\
Hospitalizations $(€)$ & $4791.08(13013.95)$ & $2995.06(8318.83)$ & $2960.87(9434.31)$ & $3490.69(10122.34)$ & $3111.33(8226.76)$ \\
Pharmaceutical Prescriptions $(€)$ & $280.06(805.00)$ & $251.11(539.34)$ & $274.79(648.04)$ & $321.98(779.25)$ & $324.73(775.82)$ \\
ART Treatment $(€)$ & $7697.00(0.00)$ & $7697.00(0.00)$ & $7697.00(0.00)$ & $7697.00(0.00)$ & $7697.00(0.00)$ \\
Total Cost $(€)$ & $14960.07(15519.86)$ & $12763.24(9337.31)$ & $12585.76(10870.28)$ & $13423.91(11495.67)$ & $13058.00(10412.49)$ \\
\hline
\end{tabular}




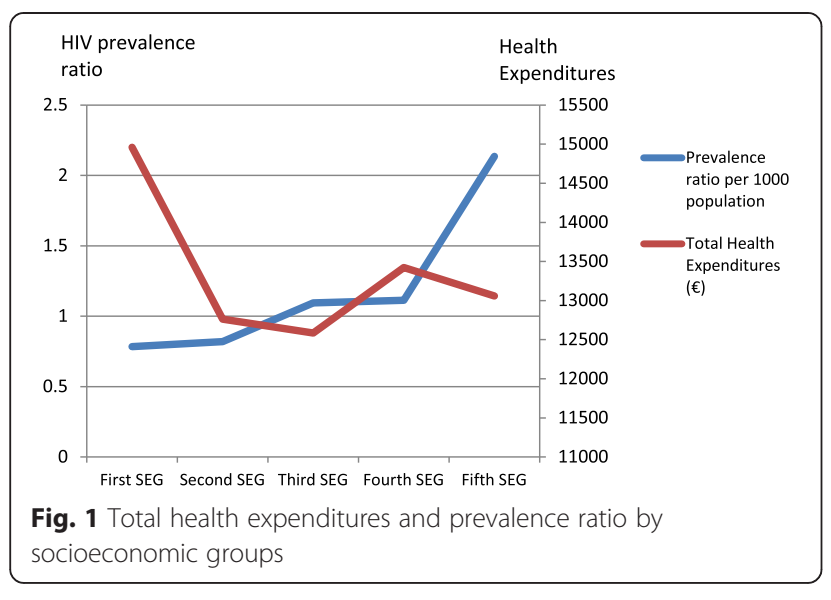

knowledge of the marginal benefits of using health services might lead richer population to demand a greater amount of health services [25].

An important goal of universal health systems is to provide equity in the access to health services for a given level of need. That involves not only access to the same ART but also the same mix of specialist, hospital, A\&E, primary care or pharmaceutical treatments. In order to reach that aim, we provide three recommendations. First, on the supply, to improve and enforce clinical guidelines for health professionals setting the type of health service provision appropriate for different levels of health need. The objective would be to reduce the discretional supply of health services and unjustifiable variability. Second, on the demand, to provide information and education programs to all HIV patients, and more specifically to those in poorer socioeconomic status about the appropriate demand of the different types of health services (when to go to primary care, specialist care, or the hospital) in order to promote the same level of use of health services. Finally, on the health system, a less fragmented organization of attention will offer a seamless transition among levels of care and improve the access of the most deprived patients to costly health services. Furthermore, we have also shown evidence on how the demand of health services by HIV patients is affected by the number of other chronic conditions they suffer and, consequently, we recommend to walk towards an integrated care model in which patients are considered as a whole, with all chronic conditions at once, instead of taking care of their multiple conditions (when that is the case) independently. This is especially important given the process of ageing and "chronification" of the HIV population. That model of integrated care might benefit from our methodology to identify especially problematic patients presenting a number of chronic conditions, which are the most expensive ones.

Unfortunately, there are some limitations in our data. First, HIV diagnosis is not complete and our data only comprehends 2635 patients. It is consequence of the historical psychological stigma of HIV patients that still makes to decrease the rate of identification of patients to about $53 \%$ (2635 out of 5002 patients receiving ART). However, after consultation with health professionals, there is no apparent bias in the lack of diagnosis by socioeconomic or demographic groups. It is more a matter of hospital personnel providing but not registering ART for any patient. Besides, our results in prevalence are consistent with other studies related to the same population [26]. Another limitation is that we excluded from our analysis the utilization of psychiatric hospitals, home and day care, transportation, prostheses, and other equipment provided to patients at home for lack of data. We suggest further research to overcome these limitations.

\section{Conclusions}

Inequality in the access to ART is the most important global concern for public health policy makers with

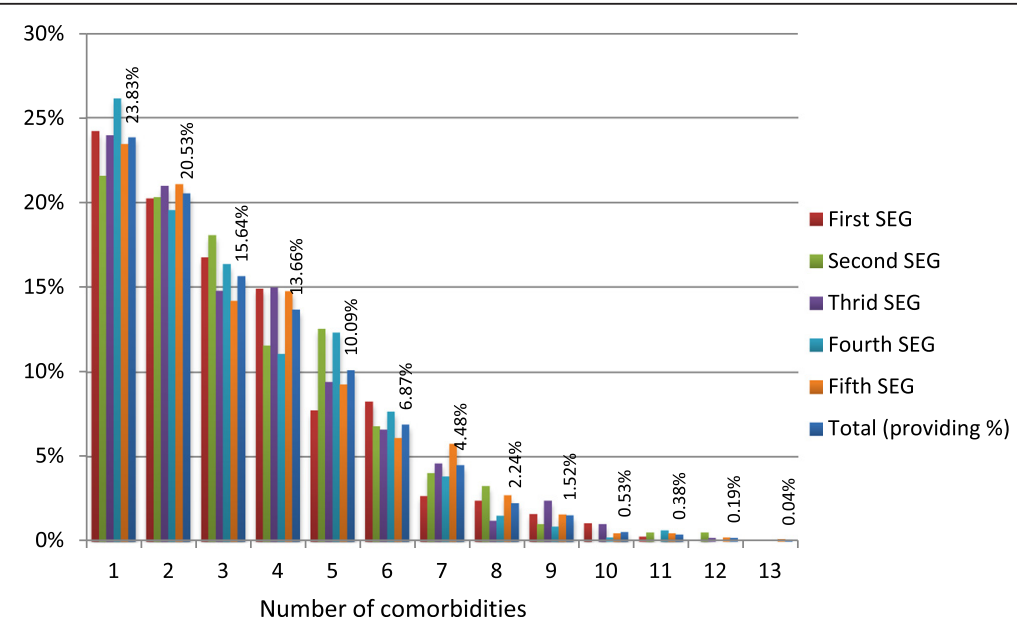

Fig. 2 Proportion of HIV patients with different number of comorbidities by socioeconomic groups (SEG) 
Table 4 OLS estimations for different types of health expenditures

\begin{tabular}{|c|c|c|c|c|c|c|c|c|c|c|c|c|}
\hline & \multicolumn{12}{|c|}{ Dependent variable. $\mathrm{N}=2365$} \\
\hline & \multicolumn{2}{|c|}{ Primary Care $(€)$} & \multicolumn{2}{|c|}{ Specialist Care $(€)$} & \multicolumn{2}{|c|}{$\begin{array}{l}\text { Accidents and } \\
\text { Emergency }(€)\end{array}$} & \multicolumn{2}{|c|}{ Hospital Care $(€)$} & \multicolumn{2}{|c|}{$\begin{array}{l}\text { Pharmaceutical } \\
\text { Prescriptions }(€)\end{array}$} & \multicolumn{2}{|c|}{ Total Health Expenditures $(€)$} \\
\hline & $\begin{array}{c}\text { Coef. } \\
\text { (std.dev.) }\end{array}$ & $\begin{array}{c}\text { Coef. } \\
\text { (std.dev.) }\end{array}$ & $\begin{array}{c}\text { Coef. } \\
\text { (std.dev.) }\end{array}$ & $\begin{array}{c}\text { Coef. } \\
\text { (std.dev.) }\end{array}$ & $\begin{array}{c}\text { Coef. } \\
\text { (std.dev.) }\end{array}$ & $\begin{array}{c}\text { Coef. } \\
\text { (std.dev.) }\end{array}$ & $\begin{array}{c}\text { Coef. } \\
\text { (std.dev.) }\end{array}$ & $\begin{array}{c}\text { Coef. } \\
\text { (std.dev.) }\end{array}$ & $\begin{array}{c}\text { Coef. } \\
\text { (std.dev.) }\end{array}$ & $\begin{array}{c}\text { Coef. } \\
\text { (std.dev.) }\end{array}$ & $\begin{array}{c}\text { Coef. } \\
\text { (std.dev.) }\end{array}$ & $\begin{array}{c}\text { Coef. } \\
\text { (std.dev.) }\end{array}$ \\
\hline age 0 to 15 & $\begin{array}{c}519,37^{* *} \\
(98,10)\end{array}$ & - & $\begin{array}{l}593,93 \\
(645,69)\end{array}$ & - & $\begin{array}{c}153,00 \\
(109,43)\end{array}$ & - & $\begin{array}{c}250,38 \\
(2408,43)\end{array}$ & - & $\begin{array}{c}48,91 \\
(178,94)\end{array}$ & - & $\begin{array}{l}9262,59^{* *} \\
(2854,04)\end{array}$ & - \\
\hline age 16 to 25 & $\begin{array}{c}252,11^{* *} \\
(60,55)\end{array}$ & $\begin{array}{c}-289,48^{* *} \\
(107,60)\end{array}$ & $\begin{array}{c}1123,02^{* *} \\
(398,53)\end{array}$ & $\begin{array}{l}538,55 \\
(739,45)\end{array}$ & $\begin{array}{c}214,93^{* *} \\
(67,54)\end{array}$ & $\begin{array}{c}51,23 \\
(124,10)\end{array}$ & $\begin{array}{c}865,42 \\
(1486,51)\end{array}$ & $\begin{array}{c}633,19 \\
(2668,21)\end{array}$ & $\begin{array}{c}27,57 \\
(110,44)\end{array}$ & $\begin{array}{l}-55,53 \\
(195,86)\end{array}$ & $\begin{array}{c}10180,05^{* *} \\
(1761,55)\end{array}$ & $\begin{array}{c}877,97 \\
(3105,87)\end{array}$ \\
\hline age 26 to 45 & $\begin{array}{c}345,29^{* *} \\
(11,64)\end{array}$ & $\begin{array}{c}-258,76^{* *} \\
(92,33)\end{array}$ & $\begin{array}{c}1283,64^{* *} \\
(76,66)\end{array}$ & $\begin{array}{l}404,06 \\
(634,53)\end{array}$ & $\begin{array}{c}209,21^{* *} \\
(12,99)\end{array}$ & $\begin{array}{c}-6,13 \\
(106,49)\end{array}$ & $\begin{array}{c}3132,94^{* *} \\
(285,95)\end{array}$ & $\begin{array}{c}1499,04 \\
(2289,64)\end{array}$ & $\begin{array}{c}204,92^{* *} \\
(21,24)\end{array}$ & $\begin{array}{c}6,77 \\
(168,07)\end{array}$ & $\begin{array}{c}12873,01^{* *} \\
(338,86)\end{array}$ & $\begin{array}{c}1644,99 \\
(2665,20)\end{array}$ \\
\hline age 46 to 65 & $\begin{array}{c}396,01^{* *} \\
(10,63)\end{array}$ & $\begin{array}{c}-238,70^{* *} \\
(92,31)\end{array}$ & $\begin{array}{c}1417,34^{* *} \\
(70,01)\end{array}$ & $\begin{array}{l}412,78 \\
(634,41)\end{array}$ & $\begin{array}{c}159,41^{* *} \\
(11,86)\end{array}$ & $\begin{array}{l}-80,22 \\
(106,47)\end{array}$ & $\begin{array}{c}3709,61^{* *} \\
(261,13)\end{array}$ & $\begin{array}{c}1412,49 \\
(2289,21)\end{array}$ & $\begin{array}{c}352,07^{* *} \\
(19,40)\end{array}$ & $\begin{array}{c}100,84 \\
(168,04)\end{array}$ & $\begin{array}{c}13731,43^{* *} \\
(309,45)\end{array}$ & $\begin{array}{c}1607,19 \\
(2664,70)\end{array}$ \\
\hline age 66 to 80 & $\begin{array}{c}576,20^{* *} \\
(45,92)\end{array}$ & $\begin{array}{l}-135,01 \\
(101,58)\end{array}$ & $\begin{array}{l}959,89^{* *} \\
(302,29)\end{array}$ & $\begin{array}{l}-402,81 \\
(698,09)\end{array}$ & $\begin{array}{c}136,23^{* *} \\
(51,23)\end{array}$ & $\begin{array}{l}-170,66 \\
(117,16)\end{array}$ & $\begin{array}{l}3280,82^{* *} \\
(1127,54)\end{array}$ & $\begin{array}{l}-883,57 \\
(2518,96)\end{array}$ & $\begin{array}{c}851,94^{* *} \\
(83,77)\end{array}$ & $\begin{array}{c}462,57^{* *} \\
(184,90)\end{array}$ & $\begin{array}{c}13502,08^{* *} \\
(1336,16)\end{array}$ & $\begin{array}{l}-1129,48 \\
(2932,15)\end{array}$ \\
\hline age over 80 & $\begin{array}{l}584,91^{* *} \\
(138,74)\end{array}$ & $\begin{array}{l}-115,25 \\
(158,95)\end{array}$ & $\begin{array}{c}543,45 \\
(913,14)\end{array}$ & $\begin{array}{c}-709,40 \\
(1092,38)\end{array}$ & $\begin{array}{c}19,12 \\
(154,75)\end{array}$ & $\begin{array}{l}-270,21 \\
(183,34)\end{array}$ & $\begin{array}{c}291,89 \\
(3406,04)\end{array}$ & $\begin{array}{l}-3089,37 \\
(3941,69)\end{array}$ & $\begin{array}{l}912,88^{* *} \\
(253,06)\end{array}$ & $\begin{array}{c}557,52 \\
(289,34)\end{array}$ & $\begin{array}{c}10049,26^{* *} \\
(4036,22)\end{array}$ & $\begin{array}{l}-3626,71 \\
(4588,25)\end{array}$ \\
\hline First quintile SEG1 & - & $\begin{array}{c}968,65^{* *} \\
(96,52)\end{array}$ & - & $\begin{array}{c}2918,92^{* *} \\
(663,35)\end{array}$ & - & $\begin{array}{l}559,58^{* *} \\
(111,33)\end{array}$ & - & $\begin{array}{c}12967,66^{* *} \\
(2393,61)\end{array}$ & - & $\begin{array}{l}931,60^{* *} \\
(175,70)\end{array}$ & - & $\begin{array}{c}26043,42^{* *} \\
(2786,23)\end{array}$ \\
\hline Second quintile SEG2 & - & $\begin{array}{c}979,53^{* *} \\
(96,13)\end{array}$ & - & $\begin{array}{c}2506,46^{* *} \\
(660,64)\end{array}$ & - & $\begin{array}{l}552,90^{* *} \\
(110,88)\end{array}$ & - & $\begin{array}{c}11063,24^{* *} \\
(2383,83)\end{array}$ & - & $\begin{array}{l}893,35^{* *} \\
(174,99)\end{array}$ & - & $\begin{array}{c}23692,50^{* *} \\
(2774,85)\end{array}$ \\
\hline Third quintile SEG3 & - & $\begin{array}{c}980,46^{* *} \\
(96,09)\end{array}$ & - & $\begin{array}{c}2331,26^{* *} \\
(660,36)\end{array}$ & - & $\begin{array}{l}528,22^{* *} \\
(110,83)\end{array}$ & - & $\begin{array}{c}10917,74^{* *} \\
(2382,84)\end{array}$ & - & $\begin{array}{l}928,36^{* *} \\
(174,91)\end{array}$ & - & $\begin{array}{c}23383,04^{* *} \\
(2773,70)\end{array}$ \\
\hline Fourth quintile SEG4 & - & $\begin{array}{c}1009,07^{* *} \\
(96,29)\end{array}$ & - & $\begin{array}{c}2599,75^{* *} \\
(661,78)\end{array}$ & - & $\begin{array}{l}562,92^{* *} \\
(111,07)\end{array}$ & - & $\begin{array}{c}11736,13^{* *} \\
(2387,95)\end{array}$ & - & $\begin{array}{l}996,83^{* *} \\
(175,29)\end{array}$ & - & $\begin{array}{c}24601,71^{* *} \\
(2779,64)\end{array}$ \\
\hline Fifth quintile SEG5 & - & $\begin{array}{c}990,29 * * \\
(95,60)\end{array}$ & - & $\begin{array}{c}2530,81^{* *} \\
(656,99)\end{array}$ & - & $\begin{array}{l}553,94^{* *} \\
(110,26)\end{array}$ & - & $\begin{array}{c}10894,76^{* *} \\
(2370,69)\end{array}$ & - & $\begin{array}{l}962,66^{* *} \\
(174,02)\end{array}$ & - & $\begin{array}{c}23629,46^{* *} \\
(2759,55)\end{array}$ \\
\hline $\begin{array}{l}\text { Suffering from } 1 \text { to } 3 \\
\text { chronic conditions }\end{array}$ & - & $\begin{array}{c}-465,86^{* *} \\
(25,34)\end{array}$ & - & $\begin{array}{c}-1979,07^{* *} \\
(174,20)\end{array}$ & - & $\begin{array}{c}-398,60^{* *} \\
(29,23)\end{array}$ & - & $\begin{array}{c}-11237,24^{* *} \\
(628,60)\end{array}$ & - & $\begin{array}{c}-890,57^{* *} \\
(46,14)\end{array}$ & - & $\begin{array}{c}-14971,34^{* *} \\
(731,71)\end{array}$ \\
\hline $\begin{array}{l}\text { Suffering from } 4 \text { to } 6 \\
\text { chronic conditions }\end{array}$ & - & $\begin{array}{c}-280,49^{* *} \\
(26,61)\end{array}$ & - & $\begin{array}{c}-1362,34^{* *} \\
(183,47)\end{array}$ & - & $\begin{array}{c}-270,03^{* *} \\
(30,79)\end{array}$ & - & $\begin{array}{c}-8513,50^{* *} \\
(662,03)\end{array}$ & - & $\begin{array}{c}-602,03^{* *} \\
(48,59)\end{array}$ & - & $\begin{array}{c}-11028,40^{* *} \\
(770,62)\end{array}$ \\
\hline $\begin{array}{l}\text { Suffering more than } 7 \\
\text { chronic conditions }\end{array}$ & - & - & - & - & - & - & - & - & - & - & - & - \\
\hline R-squared & 0.4860 & 0.5538 & 0.2125 & 0.2548 & 0.1486 & 0.2098 & 0.1117 & 0.2133 & 0.1701 & 0.2826 & 0.5755 & 0.6373 \\
\hline
\end{tabular}


respect to HIV. Under a NHS, with universal coverage and mostly free at the point of use, all HIV patients have equal right to ART and other health services provision. However, our analysis shows that they do not equally use the different types of health services. We have found evidence that HIV patients in the richest socioeconomic groups utilize more specialist and hospital care than poorer patients; and HIV patients in the poorest socioeconomic groups utilize more primary care and pharmaceutical products than richer patients. Hence, there might be some barriers preventing all patients to equally demand every type of health service. While we do not state which is the optimal mix of types of health services by health need, we understand that a universal health system should search for equal provision to patients of equal need no matter their socioeconomic status. We have pointed the different mix in the demand to barriers related to information and educational levels. Our recommendations are based on implementing accurate clinical guidelines in the mix of health services provision by need, determined by experts, so that the deviations to the supply are reduced; to provide information and educational programs for all but specifically for poorer HIV patients so that they understand better when and to which health provider they should demand health provision; and to walk towards an integrated care system in which all conditions suffered by the patient are taken into account at once. Those recommendations should help policy makers in the search for equity not only in the legal access to ART and other health services, but also in their actual demand and provision by HIV patients only based on need.

\section{Ethics committee approval}

This database is property of the Basque Health Service and the access to it is restricted. The Clinical Research Ethics Committee of the Basque Country approved this study according to the Spanish Law 14/2007 on Biomedical Research, the Ethical Principles for Medical Research of the Declaration of Helsinki and other applicable ethical principles. All individual information has previously to this study been codified in order to ensure patient confidentiality. Written consent by the patients was specifically waived by the approving Committee.

\section{Abbreviations}

HIV: Human Immunodeficiency Virus; ART: Antiretroviral Therapy; PREST: Population Risk Stratification Program; DRGs: Diagnosis Related Groups; ICD-9-CM: The International Classification of Diseases, Ninth Revision, Clinical Modification; DI: Deprivation Index; SEG: Socioeconomic Groups; NHS: National Health Service; A\&E: Accident and Emergency.

\section{Competing interests}

Manuel García-Goñi research was funded by the project "Evaluating Preferences for Equity and Efficiency among National/Regional Health Policy Makers", financed by the Spanish Institute for Fiscal Studies. There was no other funding for other coauthors. There are no conflicts of interest for any of the authors.

\section{Authors' contributions}

MGG had overall responsibility for the first and second draft, design of the experiment, analysis and estimations, interpretation of data, writing and general review. RNS contributed to the general review of the manuscript, provided access to the data, interpretation of data and design of the experiment. FP contributed to the general review of the manuscript and writing, interpretation of data and design of the experiment. JFO contributed to the general review of the manuscript, provided access to the data, interpretation of data and design of the experiment. All authors contributed to the overall design and approach, and approved the final manuscript.

\section{Acknowledgments}

We are grateful to the attendants at the Spanish Health Economics Association Conference for helpful comments on an earlier draft, to the MEDEA research team in the Basque Country for the calculation and provision of the deprivation index, and to anonymous referees for their comments and suggestions. Also, we want to explicitly thank Montse Calvo for her work in geocodifying the data. Remaining errors are the authors' responsibility.

\section{Author details}

'Departamento de Economía Aplicada II, Universidad Complutense de Madrid, Campus de Somosaguas, 28223 Pozuelo de Alarcón, Madrid, Spain. ${ }^{2}$ Deusto Business School, University of Deusto, Bilbao, Spain. ${ }^{3}$ Centro de Salud de Astrabudua, Osakidetza - Basque Health Service, Erandio, Spain.

${ }^{4}$ University of Murdoch, Perth, Australia. ${ }^{5}$ University of Bologna, Bologna, Italy.

Received: 25 February 2015 Accepted: 12 September 2015

Published online: 29 October 2015

\section{References}

1. World Health Organization. Global Health Observatory Data Repository. 2013. Available online at: http://apps.who.int/gho/data/ node.main.621?lang=en) (accessed on December 7, 2014

2. Piot P, Quinn TC, Taelman H, Feinsod FM, Minlangu KB, Wobin O, et al. Acquired immunodeficiency syndrome in a heterosexual population in Zaire. Lancet. 1984;2:65-9.

3. Ham C. The ten characteristics of the high-performing chronic care system. Health Econ Policy Law. 2010;5(Pt 1):71-90.

4. OECD. OECD Health Statistics 2014 [online database]. Paris, Organisation for Economic Co-operation and Development. Available at: http:// www.oecd.org/health/health-systems/oecd-health-statistics-2014-frequentlyrequested-data.htm (Accessed on December 17, 2014).

5. Wagner EH, Austin BT, Von Korff M. Organizing care for patients with chronic illness. Milbank Quarterly. 1996;74(4):511-44.

6. Jadad AR, Cabrera A, Martos F, Smith R, Lyons RF. When people live with multiple chronic diseases: a collaborative approach to an emerging global challenge. Granada: Andalusian School of Public Health; 2010. Available at http://www.opimec.org/equipos/when-people-live-with-multiple-chronicdiseases (accessed on December 3, 2014).

7. World Health Organization. HIV/AIDS. Fact sheet N³60. 2013. Available online at: http://www.who.int/mediacentre/factsheets/fs360/en/index.html (accessed on December 7, 2014).

8. Gilks CF, Crowley S, Ekpini R, Gove S, Perriens J, Souteyrand Y, et al. The WHO public-health approach to antiretroviral treatment against HIV in resource-limited settings. Lancet. 2006;368:505-10.

9. Cohen MS, Smith MK, Muessig KE, Hallett TB, Powers KA, Kashuba AD. Antiretroviral treatment of HIV-1 prevents transmission of HIV-1: where do we go from here? Lancet. 2013;382:1515-24.

10. Mermin J, Were W, Ekwaru JP, Moore D, Downing R, Behumbiize P, et al. Mortality in HIV-infected Ugandan adults receiving antiretroviral treatment and survival of their HIV-uninfected children: a prospective cohort study. Lancet. 2008:371:752-59.

11. Beyrer C, Crago AL, Bekker LG, Butler J, Shannon K, Kerrigan D, et al. An action agenda for HIV and sex workers. Lancet. 2015; 385:287-301.

12. Wolfe D, Carrieri MP, Shepard D. Treatment and care for injecting drug users with HIV infection: a review of barriers and ways forward. Lancet. 2010;376:355-66. 
13. Penazzato M, Revill P, Prendergast AJ, Collins IJ, Walker S, Elyanu PJ, et al. Personal view early infant diagnosis of HIV infection in low-income and middle-income countries: does one size fit all? Lancet Infect Dis 2014;14:650-55.

14. García-Goñi M, Hernández-Quevedo C, Nuño-Solinís R, Paolucci F. Pathways towards Chronic-care Focused Healthcare Systems: evidence from Spain. Health Policy. 2012;108:236-45.

15. Spanish Institute of Health Information: (2012) Spanish version (eCIE9MC) of the Electronic International Classification of Diseases, Ninth Revision, Clinical Modification (ICD-9-CM) (8th Ed., Version 1.1.0). Available at: http:// www.msssi.gob.es/en/estadEstudios/estadisticas/docs/CIE9MC_8ed.pdf (Accessed on December 7, 2014).

16. World Health Organization (2012). The WHO Collaborating Centre for Drug Statistics Methodology (2012) International language for drug utilization research ATC/DDD. Available: http://www.whocc.no/atc_ddd_index (Accessed on December 7, 2014).

17. Domínguez-Berjón MF, Borrell C, Cano-Serral G, Esnaola S, Nolasco A Pasarín Ml, et al. Constructing a deprivation index based on census data in large Spanish cities (the MEDEA project)]. Gac Sanit. 2008;22:179-87.

18. Van de ven WPMM, Ellis RP. Risk adjustment in competitive health plan markets. In: Anthony J. Culyer, Joseph P, editors. Handbook of Health Economics. Chapter 14. Vol. 1, Part A. Newhouse: Elsevier; 2000. p. 755-845.

19. Barnett K, Mercer SW, Norbury M, Watt G, Wyke S, Guthrie B. Epidemiology of multimorbidity and implications for health care, research, and medical education: a cross-sectional study. Lancet. 2012;380:37-43.

20. The Johns Hopkins ACG ${ }^{\oplus}$ Technical Reference Guide. Version 9.0. Baltimore, MD; 2009

21. Orueta JF, García-Álvarez A, García-Goñi M, Paolucci F, Nuño-Solinís R. Prevalence and costs of multimorbidity by deprivation levels in the Basque country: a population based study using health administrative databases. PLoS One. 2014;9(2), e89787.

22. Dixon A, Le Grand J, Henderson J, Murray R, Poteliakhoff E. Is the British National Health Service equitable? The evidence on socioeconomic differences in utilization. J Health Serv Res Policy. 2007;12:104-9.

23. Gonzalo T, García-Goñi M, Muñoz-Fernández MA. Socio-economic impact of Antiretroviral Tretament in HIV patients. An economic review of costs savings after introduction of HAART. AIDS Rev. 2009:11:79-90.

24. Wawrzyniak AJ, Ownby RL, McCoy K, Waldrop-Valverde D. Health Literacy: Impact on the Health of HIV-Infected Individuals. Curr HIV/AIDS Rep. 2013;10(4):295-304

25. Kenkel D. Consumer health information and the demand for medical care. Rev Econ Stat. 1990;72(4):587-95.

26. Esnaola S, Aldasoro E, Ruiz R, Audicana C, Pérez Y, Calvo M. Socioeconomic inequalities in mortality in the Basque Country [Spain]. Gac Sanit. 2006;20(1):16-24

\section{Submit your next manuscript to BioMed Central and take full advantage of:}

- Convenient online submission

- Thorough peer review

- No space constraints or color figure charges

- Immediate publication on acceptance

- Inclusion in PubMed, CAS, Scopus and Google Scholar

- Research which is freely available for redistribution

Submit your manuscript at www.biomedcentral.com/submit 